\title{
D'une chaîne l'autre, normes et variations dans le débitage laminaire magdalénien
}

Sylvie Ploux, Claudine Karlin et Pierre Bodu

\section{(2) OpenEdition \\ 12 Journals}

Édition électronique

URL : https://journals.openedition.org/tc/687

DOI : $10.4000 /$ tc. 687

ISSN : 1952-420X

Éditeur

Éditions de l'EHESS

\section{Édition imprimée}

Date de publication : 1 novembre 1992

ISSN : 0248-6016

\section{Référence électronique}

Sylvie Ploux, Claudine Karlin et Pierre Bodu, « D'une chaîne l'autre, normes et variations dans le débitage laminaire magdalénien », Techniques \& Culture [En ligne], 17-18| 1992, mis en ligne le 10 janvier 2006, consulté le 29 septembre 2022. URL : http://journals.openedition.org/tc/687 ; DOI : https://doi.org/10.4000/tc.687

Ce document a été généré automatiquement le 29 septembre 2022.

Tous droits réservés 
D'une chaîne l'autre, normes et variations dans le débitage laminaire magdalénien

Sylvie Ploux, Claudine Karlin et Pierre Bodu 